\title{
Brand website marketing strategies for foods and beverages consumed by children and adolescents in Argentina
}

\author{
Paula Gómez, B.S. ${ }^{a}$, Camila Tamburini, B.S. ${ }^{a}$, Vanesa Rodríguez García, B.S. ${ }^{a}$, Verónica Chamorro, B.S. ${ }^{a}$ and \\ Esteban Carmuega, M.D. ${ }^{a}$
}

\begin{abstract}
The Internet has allowed the expansion of food and beverage advertising in different media. The objective of this study was to identify the marketing strategies used in brand websites of foods and beverages consumed by children and adolescents, and classify them based on the Food Guidelines for the Argentinean Population.

The foods and beverages most commonly consumed by the child and adolescent population as per the Survey on Nutritional Food Intake of the Autonomous City of Buenos Aires were selected. Brand websites were identified; marketing strategies were analyzed and marketed foods and beverages were classified based on the Guidelines.

A total of 80 websites were found; the most common strategies were brand identity, benefits and claims, and links to websites and / or social media. Also, $30 \%$ of sites were aimed at children and adolescents, and $75 \%$ of marketed foods and beverages corresponded to the group of sweets and fats, including those of low nutritional value.

Key words: marketing, websites, foods and beverages, child, adolescent.
\end{abstract}

http: / / dx.doi.org/10.5546/ aap.2021.eng.51

To cite: Gómez P, Tamburini C, Rodríguez García V, Chamorro V, Carmuega E. Brand website marketing strategies for foods and beverages consumed by children and adolescents in Argentina. Arch Argent Pediatr 2021;119(1):51-55.

a. Child Nutrition Study Center (Centro de Estudios sobre Nutrición Infantil), Autonomous City of Buenos Aires.

E-mail address:

Paula Gómez, B.S.: paula.gomez@cesni.org.ar

Funding: This research study was financed with the Institution's own funds.

Conflict of interest: None.

Received: 5-1-2020

Accepted: 8-18-2020

\section{INTRODUCTION}

The Internet has allowed the expansion of promotion and advertisement in different media, including websites, social media platforms, apps, and online games and videos. ${ }^{1-3}$ Several studies have demonstrated that foods and beverages advertised in the mass media are high in energy, added sugars, and total fats, and may be one of the factors associated with the increase in childhood overweight and obesity. ${ }^{4-7}$ In Argentina, according to the Second National Survey on Nutrition and Health (2018), $20.7 \%$ of the 5-17-year-old population is overweight and $20.4 \%$, obese. $^{8}$

The World Health Organization has stated that companies are using the new communication technologies to market foods to children and adolescents in Latin America. ${ }^{9,10}$ In recent years, several studies observed the use of specific marketing strategies to target this population in food company websites. ${ }^{11-13}$ In this type of media, marketing is defined as a promotional activity characterized by both the use of creative techniques and data analysis of web users so as to maximize impact. ${ }^{2}$

The evidence on this subject is limited in Argentina, as well as in the rest of Latin America. ${ }^{14}$ The objective of this study was to identify the marketing strategies used in brand websites of foods and beverages consumed by children and adolescents, and classify them based on the Food Guidelines for the Argentinean Population.

\section{POPULATION AND METHODS}

This was a descriptive, cross-sectional study. The foods and beverages consumed by more than $5 \%$ of the 5-17-year-old population according to the Survey on Nutritional Food Intake of the Autonomous City of Buenos Aires (2011) were selected to guide the search of websites that may include advertising aimed at children and adolescents. This survey had a probability cluster sampling design and included 1987 individuals who underwent a 24-hour recall interview to record food and beverage consumption.

To identify available brands of the foods and beverages selected for analysis, the online 
catalogs of the main supermarket chains of the Autonomous City of Buenos Aires were searched and products were ordered by relevance. Foods and beverages that did not have a commercial brand were excluded (Table 1).

For each selected brand, a search was done in Google ${ }^{\circledR}$ using the brand as a key word in order to check if they had a website; the search was restricted to Argentine websites and excluded corporate websites of food companies. The models developed in other studies ${ }^{11,12}$ were adapted to analyze marketing strategies. Strategies were classified into eight categories: I) brand identity; II) sections and gaming; III) promotions;

TABLE 1. Analyzed food and beverage categories and number of brands included

\begin{tabular}{|c|c|c|}
\hline Food or beverage & Percentage of consumers* & Number of studied brands \\
\hline Sunflower oil & 76.9 & 5 \\
\hline Sugar & 61.8 & 3 \\
\hline Eggs & 61.3 & 2 \\
\hline Fluid whole milk & 52.6 & 6 \\
\hline Regular soft drinks & 45.6 & 12 \\
\hline Butter & 33.1 & 3 \\
\hline Noodles & 31.8 & 11 \\
\hline Cocoa powder & 30.8 & 3 \\
\hline Rice & 28.2 & 4 \\
\hline Grated cheese & 26.8 & 3 \\
\hline Canned tomatoes & 26.1 & 5 \\
\hline Chicken & 25.4 & 3 \\
\hline Wheat flour & 24.1 & 3 \\
\hline Powder juice & 22.2 & 3 \\
\hline Fluid reduced-fat milk & 23.4 & 6 \\
\hline Semi-hard cheese & 22.8 & 3 \\
\hline Ham & 22.6 & 5 \\
\hline Soft cheese & 20.5 & 5 \\
\hline Mayonnaise & 17.3 & 5 \\
\hline Sweet cookies & 17.1 & 15 \\
\hline Turnover dough & 15.2 & 2 \\
\hline Apple & 14.9 & 4 \\
\hline Crackers & 14.7 & 9 \\
\hline Diet powder juice & 14.1 & 4 \\
\hline Banana & 13.9 & 3 \\
\hline Filled biscuits & 13.5 & 17 \\
\hline Chocolate cookie sandwich & 12.9 & 13 \\
\hline Mozzarella & 11.5 & 3 \\
\hline Dulce de leche & 11.4 & 5 \\
\hline Flavored waters & 11.0 & 6 \\
\hline Sliced bread & 10.5 & 5 \\
\hline Yogurt & 10.1 & 7 \\
\hline Vienna sausages & 8.4 & 5 \\
\hline Candies & 7.5 & 11 \\
\hline Chocolate & 7.5 & 13 \\
\hline Dairy cream & 7.2 & 4 \\
\hline Cream cheese & 6.9 & 5 \\
\hline Diet soft drinks & 6.9 & 12 \\
\hline Potato chips & 6.9 & 5 \\
\hline Sugary breakfast cereals & 6.8 & 14 \\
\hline Patties & 6.7 & 4 \\
\hline Processed juice & 6.2 & 5 \\
\hline Cereal bars & 6.0 & 4 \\
\hline Assorted sweet cookies & 5.6 & 3 \\
\hline Milk desserts & 5.5 & 6 \\
\hline Olive oil & 5.2 & 8 \\
\hline Chocolate milk & 5.0 & 5 \\
\hline Pre-fried chicken products & 5.0 & 4 \\
\hline Gelatin & 5.0 & 5 \\
\hline
\end{tabular}

* Data from the Survey on Nutritional Food Intake of the Autonomous City of Buenos Aires (2011). 
IV) characters and celebrities; v) links to websites and / or social media; vI) benefits and claims; VII) registration and downloads, and VIII) protection and legal aspects. Strategies were identified on the main page and on those that were within two mouse clicks from that page.
Websites were considered aimed at children and adolescents if they used strategies such as animated characters or cartoons, celebrities, games, apps, competitions or events targeted at attracting this audience by appealing to fun, adventure, fantasy, and fashion themes. ${ }^{12}$

TABLE 2. Marketing strategies used in food and beverage websites

\begin{tabular}{|c|c|}
\hline & $\begin{array}{c}\text { Total websites } \\
(\mathrm{n}=80) \\
\text { Number }(\%) \\
\end{array}$ \\
\hline $\begin{array}{l}\text { Brand identity } \\
\text { Presence of brand logo } \\
\text { Presence of product package } \\
\text { Product as part of the background } \\
\text { Presence of other brand product variants }\end{array}$ & $\begin{array}{l}80(100) \\
79(98.8) \\
70(87.5) \\
60(75) \\
60(75)\end{array}$ \\
\hline $\begin{array}{l}\text { Benefits and claims } \\
\text { Presence of recipes } \\
\text { Nutrition information } \\
\text { Brand benefit claims } \\
\text { Nutrition claims } \\
\text { Healthy eating information } \\
\text { Health claims in general }\end{array}$ & $\begin{array}{l}71(88.8) \\
47(58.8) \\
41(51.3) \\
29(36.3) \\
28(35) \\
13(16.3) \\
11(13.8)\end{array}$ \\
\hline $\begin{array}{l}\text { Links to websites and/or social media } \\
\text { Link the brand's social media (Facebook and / or Instagram) } \\
\text { Presence of social media postings (Facebook and/or Instagram) } \\
\text { Brand television advertisement } \\
\text { Link to other company brands } \\
\text { Links to other food websites } \\
\text { Links to other non-food websites }\end{array}$ & $\begin{array}{l}68(85) \\
65(81.3) \\
16(20) \\
11(13.8) \\
9(11.3) \\
3(3.8) \\
0(0)\end{array}$ \\
\hline $\begin{array}{l}\text { Protection and legal aspects } \\
\text { Legal information } \\
\text { Terms of use and cookies } \\
\text { Adult consent } \\
\text { Age block }\end{array}$ & $\begin{array}{l}46(57.5) \\
46(57.5) \\
4(5) \\
0(0) \\
0(0)\end{array}$ \\
\hline $\begin{array}{l}\text { Registration and downloads } \\
\text { Website membership } \\
\text { Online store } \\
\text { Apps } \\
\text { Unbranded educational material } \\
\text { Branded educational material } \\
\text { Benefits for members } \\
\text { Coloring pictures or images for electronic devices }\end{array}$ & $\begin{array}{c}20(25) \\
13(16.3) \\
7(8.8) \\
2(2.5) \\
2(2.5) \\
1(1.3) \\
1(1.3) \\
0(0)\end{array}$ \\
\hline $\begin{array}{l}\text { Characters and celebrities } \\
\text { Presence of cartoons } \\
\text { Presence of animated characters } \\
\text { Presence of famous people or celebrities (television, radio, films, social media, music) } \\
\text { Presence of sports figures }\end{array}$ & $\begin{array}{l}15(18.8) \\
6(7.5) \\
5(6.3) \\
3(3.8) \\
1(1.3)\end{array}$ \\
\hline $\begin{array}{l}\text { Sections and gaming } \\
\text { Designated section with content for children and adolescents } \\
\text { Games including the brand } \\
\text { Designated family section } \\
\text { Games that do not promote the brand }\end{array}$ & $\begin{array}{l}11(13.8) \\
8(10) \\
5(6.3) \\
2(2.5) \\
0(0)\end{array}$ \\
\hline $\begin{array}{l}\text { Promotions } \\
\text { Competitions } \\
\text { Giveaways } \\
\text { Fundraiser opportunities }\end{array}$ & $\begin{array}{c}11(13.8) \\
7(8.8) \\
4(5) \\
1(1.3)\end{array}$ \\
\hline
\end{tabular}


Foods and beverages that had a website were classified based on the Guidelines as follows: I) fruits and vegetables; II) legumes, cereals, potato, bread, and pasta; III) milk, yogurt, and cheese; IV) meat and eggs; v) oil, tree nuts, and seeds; and vI) sweets and fats. ${ }^{15}$ The first five groups provide nutrients, so the recommendation is to consume them on a daily basis. The sweets and fats group includes foods and beverages high in fats, sugars, and salt, so their consumption should be limited.

A Google ${ }^{\circledR}$ form was developed to record data, and a pilot test was done. Data were collected between August and September 2019. The Statistical Package for the Social Sciences, version 20 for Windows, was used for the statistical analysis.

\section{Ethical considerations}

All aspects related to the development of this project have been conducted in accordance with valid national and international standards.

\section{RESULTS}

A total of 195 food and beverage brands were selected (Table 1). Of these brands, $41 \%(\mathrm{n}=80)$ had a website; 24 were aimed at children and adolescents.

Among all websites analyzed, brand identity was the most commonly used strategy $(100 \%$ of sites); in this category, it was observed that $99 \%$ of sites showed the brand logo and $88 \%$, the package. Benefits and claims was the second most common strategy (89\%); in this category, the presence of recipes $(59 \%)$ and nutrition information $(51 \%)$ were the most frequent ones. Links to websites and/or social media were the third most common strategy; in this case, a link to the brand's social media was the most used technique ( $81 \%)$. In addition, protection and legal aspects was observed in $58 \%$ of websites. Registration and downloads $(25 \%)$ and characters and celebrities (19\%) were observed to a lesser extent. The less common strategies were promotions $(14 \%)$ and sections and gaming $(14 \%)$ (Table 2$)$.

Foods and beverages marketed on websites were classified according to the Guidelines. It was observed that $63 \%$ corresponded to the sweets and fats group, followed by milk, yogurt, and cheese $(13 \%)$, legumes, cereals, potatoes, bread, and pasta $(10 \%)$, fruits and vegetables $(8 \%)$, oil and seeds (5\%), and meat and eggs (1\%). The analysis of the foods and beverages found in the sites aimed at children and adolescents showed a higher proportion of sweets and fats $(75 \%)$; this group included sugar-sweetened beverages, chocolate milk, sweet cookies, confectionery, sugary cereals, milk desserts, and Vienna sausages. This was followed by the milk, yogurt, and cheese group (11\%), then the legumes, cereals, potato, bread, and pasta group $(7 \%)$, the oil and seeds group (4\%), and finally, fruits and vegetables $(4 \%)$.

\section{DISCUSSION}

In Argentina, the most common strategies were the presence of the brand logo and of the product package. This was consistent with the data provided by Kelly et al., who reviewed 119 Australian food company websites, ${ }^{11}$ and with the results of a study that analyzed 70 food and beverage websites from New Zealand. ${ }^{12}$ In addition, in Australia, brand benefits and educational material downloads were among the most frequent strategies. ${ }^{11}$ The study by Weber et al. found that the most common strategies observed in United States websites were registration and downloads, promotions, gaming, and presence of characters. ${ }^{13}$ These strategies were less common in Argentine websites.

The percentage of websites that targeted their strategies at children and adolescents in Argentina was $30 \%$, similar to the study done in New Zealand, where $34 \%$ of websites were aimed at this audience. ${ }^{12}$ In the study by Kelly et al., they accounted for $13 \%{ }^{11}$

Using the Guidelines to analyze marketed foods and beverages, it was observed that those high in fats, sugars, and salt had a greater presence in websites aimed at children and adolescents. This was consistent with the results of other studies. According to the Ministries of Health of Australia ${ }^{11}$ and New Zealand, ${ }^{12} 61 \%$ and $75 \%$ of products, respectively, corresponded to the unhealthy category.

The main strength of our study is that it provides unprecedented data because it is the first one of this type conducted in Argentina. However, the dynamics of the online world demand the assessment of trends and expand the field of research to other digital media, like social platforms, virtual gaming, and websites frequently used by children and adolescents. A weakness of the study is that, since it was not possible to assess website traffic, it provides no quantitative information to measure actual exposure to food and beverage marketing.

Our society deserves a comprehensive 
discussion about the use of marketing strategies aimed at children and adolescents in the online world. This is especially true when the marketed foods and beverages have a low nutritional quality, according to the results of this study.

\section{CONCLUSION}

It was observed that 24 out of the 80 analyzed websites included strategies aimed at attracting children and adolescents and that 7.5 out of 10 marketed foods and beverages were of low nutritional value.

\section{Acknowledgments}

The authors would like to thank María Elisa Zapata, M.D., and Alicia Rovirosa, Biochemist, for their valuable input reviewing this document.

\section{REFERENCES}

1. Regional Office for Europe of the World Health Organization. Marketing of foods high in fat, salt and sugar to children: update2012-2013. Denmark: WHO;2013. [Accessed on: April 24t ${ }^{\text {th }}$, 2020]. Available at: http: / / www. euro.who.int/__data/ assets / pdf_file / 0019/191125/ e96859.pdf.

2. Regional Office for Europe of the World Health Organization. Tackling food marketing to children in a digital world: trans-disciplinary perspectives. Copenhagen, Denmark: WHO, 2016. [Accessed on: June 20 ${ }^{\text {th }}, 2020$ ]. Available at: https:/ / www.euro.who.int/data/assets / pdf_file/0017/322226/Tackling-food-marketing-childrendigital-world-trans-disciplinary-perspectives-en.pdf.

3. World Cancer Research Fund International. Building Momentum: Lessons on implementing robust restrictions of food and non-alcoholic beverage marketing to children. 2020. [Accessed on: July $5^{\text {th }}, 2020$ ]. Available at: https: / / www.wcrf.org/sites/default/files / PPA-BuildingMomentum-3-WEB-3.pdf.

4. Cairns G, Angus K, Hastings G, Caraher M. Systematic reviews of the evidence on the nature, extent and effects of food marketing to children. A retrospective summary. Appetite. 2013; 62:209-15.

5. Organización Mundial de la Salud. Informe de la Comisión para acabar con la obesidad infantil. Génova: OMS, 2016. [Accessed on: April 24 $\left.{ }^{\text {th }}, 2020\right]$. Available at: https://apps.who.int/iris/bitstream/ handle/10665/206450/9789243510064_spa.pdf;jsessioni $\mathrm{d}=$ DAE6B5DA0C2C4A2587A7E1FD61487939? sequence=1.
6. Rovirosa A, Zapata ME, GómezP, GotthelfS, etal. Alimentos y bebidas publicitados en canales infantiles de Argentina: frecuencia, duración y calidad nutricional. Arch Argent Pediatr. 2017; 115(1):28-34.

7. Sadeghirad B, Duhaney T, Motaghipisheh S, Campbell NR, et al. Influence of unhealthy food and beverage marketing on children's dietary intake and preference: a systematic review and meta-analysis of randomized trials. Obes Rev. 2016; 17(10):945-59.

8. Argentina. Secretaría de Gobierno de Salud. Segunda Encuesta Nacional de Nutrición y Salud. Resumen Ejecutivo. Ministerio de Salud; 2018. [Accessed on: April 20 ${ }^{\text {th }}$, 2020]. Available at: http: / / www. msal.gob.ar/images/stories/bes/graficos/0000001565cntennys2_resumen-ejecutivo-2019.pdf.

9. Organización Panamericana dela Salud. Recomendaciones dela consulta de expertos dela Organización Panamericana de la Salud sobre la promoción y publicidad de alimentos y bebidas no alcohólicas dirigida a los niños en la Región de las Américas. Washington, DC: OPS, 2011. [Accessed on: April 24 $\left.4^{\text {th }}, 2020\right]$. Available at: https://www.paho. org / hq/dmdocuments / 2012 / Experts-Food-Marketingto-Children-(SPA).pdf.

10. Organización Mundial de la Salud. Conjunto de recomendaciones sobre la promoción de alimentos y bebidas noalcohólicas dirigida a los niños. Suiza:OMS, 2010. [Accessedon:April4 ${ }^{\text {th }}$,2020].Availableat:https: / / apps.who. int / iris / bitstream/ handle/10665/44422/9789243500218_ spa.pdf;jsessionid=78872EDFBE0C912DED76166671CDA F8A? sequence $=1$.

11. Kelly B, Bochynska K, Kornman K, Chapman K. Internet food marketing on popular children's websites and food product websites in Australia. Public Health Nutr. 2007; 11(11):1180-7.

12. Vandevijvere S, Sagar K, Kelly B, Swinburn B. Unhealthy food marketing to New Zealand children and adolescents through the internet. N Z Med J. 2017; 130(1450):32-43.

13. Weber K, Story M, Harnack L. Internet food marketing strategies aimed at children and adolescents: a content analysis of food and beverage brand web sites. J Am Diet Assoc. 2006; 106(9):1463-6.

14. Chemas-Velez MM, Gómez LF, Velasquez A, Mora-Plaza $\mathrm{M}$, et al. Scoping review of studies on food marketing in Latin America:Summary of existing evidence and research gaps. Rev Saude Publica. 2019; 53:107.

15. Guías alimentarias para la población Argentina. Documento técnico metodológico. Buenos Aires: Ministerio de Salud de la Nación; 2016. [Accessed on: February 28 $\left.{ }^{\text {th }}, 2020\right]$. Available at: http:/ / www.msal.gob.ar/images/stories / bes / graficos / 0000001007cnt-2017-06_guia-alimentariapoblacion-argentina.pdf. 